Open Access

\title{
Assessing the role of market integration in the consumption of traditional foods in Benin: a joint price instability coefficient and diet composition approach
}

\author{
Barthelemy G. Honfoga ${ }^{* *}$, Gervais N'tandou-Bonzitou ${ }^{2}$, Raymond S. Vodouhè ${ }^{2}$, Mauricio R. Bellon ${ }^{3}$
} and Joseph D. Hounhouigan ${ }^{1}$

\author{
* Correspondence: \\ honfogabg@yahoo.fr \\ ${ }^{1}$ Faculty of Agronomic Sciences, \\ University of Abomey-Calavi, 03 BP \\ 2819 Cotonou, Jericho, Benin \\ Full list of author information is \\ available at the end of the article
}

\begin{abstract}
Globalization-driven food trade policies and the transformations of food regimes have led to modernizing food habits and the growing substitution of traditional foods by introduced/industrialized foods in the diets of urban people in sub-Saharan Africa. Such changes in food consumption habits are suspected to be associated with the increasing prevalence of some non-transmittable food-related diseases in the region. The role food markets play in food substitution in the diets needs to be understood. This study analyzes the effects of differential market integration on the consumption of the two types of foods in Southern Benin. Market integration was assessed using the reciprocal of the gap in price instability coefficients between markets $(G)$ and calculated using monthly prices series over the "July 2009-July 2011" period. The findings indicate that markets in the Allada market cluster are more integrated for introduced foods $(G=5.3)$ than traditional foods $(G=4.3)$. The integration of primary, assembly, and rural consumer markets with the Bohicon regional market is by far higher for introduced foods $(G=5.3$ ) than traditional foods $(G=1.2)$. The results in Toffo market cluster were comparable, in spite of less reliable data. The district-level rural markets are more integrated among themselves than with the regional market, either for traditional foods or introduced foods. Considering that most of the latter are processed foods, the result tends to indicate that food processing would trigger greater market integration. Therefore, policies that promote processing and trade of locally produced traditional foods should be implemented. Indeed, processing is key among the factors that increase urban consumers' preferences for introduced foods against traditional foods. On the contrary, the hypothesis which asserts that low levels of market integration among traditional foods contribute to their disappearance in people's diets is rejected. Indeed, diets in rural areas of Benin are still dominated by "traditional foods." However, the growing trend in the consumption of imported low nutritional value foods should be controlled by appropriate food production and trade policies.
\end{abstract}

Keywords: Market integration, Price instability coefficients, Traditional foods, Introduced foods, Food consumption, Food trade policies 


\section{Background}

\section{Research background, objectives, and hypotheses}

A diversity of foods is available to enhance people's food security in sub-Saharan Africa (SSA), through not only agricultural production and trade but also harvest of wild plants and animals in the nature (FAO/PAR 2010, Assogbadjo et al. 2011). However, this diversity is underutilized today (Dansi et al. 2008) due to the transformations of food systems that are taking place worldwide (Gómez et al., 2013). These transformations evolved from the first to the second food régime, leading to the increasing abandonment of traditional foods and their replacement with introduced/manufactured foods as a result of increased dependence on modern food businesses for food procurement (Atkins and Bowler, 2001). Such a change is being linked with the increasing occurrence in Africa of some food-related non-transmittable diseases (Abegunde et al. 2007). In many African countries, modernizing food habits go with the belief that "foreign is better" (Nzenza 2014). Although that belief is not the sole reason, policies that have silently pushed for such change in food habits over decades have finally created that belief. This is particularly true in Benin where the cotton-biased agricultural policy and investment can be blamed, as it has made food procurement largely dependent on imports, mostly for rice, vegetal oil, and meat and dairy products. For example, the import dependency rate ${ }^{1}$ for rice increased from $34.8 \%$ in $1999-2005$ to $46.5 \%$ in $2005-$ 2013 (FAO/ECOWAS 2015). The annual growth rate of vegetal oil imports (about $18 \%$ ) is highest among all agricultural products in West Africa, followed by meat, drinks, fruits, and legumes (Hollinger and Staatz 2015). The growing rice imports in Benin could be explained also by the low competitiveness of local rice (Adegbola and Singbo 2005). Indeed, the preference attributes of imported rice-especially cleanness, whiteness, and flavor mostly accruing from industrial processing-are not favorable to local rice (Arinloye 2006). Some macroeconomic variables are overarching explanatory factors. For example, the agricultural sector contribution to GDP decreased from 34\% in 1995 to 29.9\% in 2008 (MAEP 2010), while high labor prices, climate change, and non-availability of specific fertilizers have made most annual traditional crops become expensive and non-accessible to the poor. As a result, most of these crops have become "underutilized and neglected crops" due to their very low productivity and poor marketing systems (Adegbola et al. 2016, Dansi et al. 2003).

Therefore, with increased availability of introduced foods in markets, poor people substitute a diversity of traditional foods with a limited number of introduced foods (Bellon 2010).

The opposite trend is also being observed as an expression of the third food régime, where consumer resistance and reaction to processed, manufactured, and fast food is growing (Dawson and Burt 1998, Atkins and Bowler 2001). The third food régime goes with a renewed recognition of the value of traditional foods and the need to restore them in the diets of people not only in the Western countries but also in the developing countries (Bowler 1992). Unlike before the 1980s when fruits and vegetables were present mostly in supermarkets and a few open selling points of Cotonou City (Benin), these foods can be observed today everywhere in urban areas. Yet, they remain expensive and non-accessible to the common citizens. They include a mix of imported fresh foodstuffs and a few imported seed-based locally produced foods. Traditional foods 
have not yet found enough their way in urban markets. Benin can be considered in the early stage of a country's food system transformation due to its low income, large share of rural population, high reliance by farmers on their own production, and high incidence of undernourishment (Gómez et al. 2013).

Hence, there is a re-evaluation of the value of traditional/local foods. There is increasing research on the value of these foods (especially, e.g., African leafy vegetables in Kenya and Benin), and the need to maintain or reintroduce them in food systems (see, e.g., Achigan Dako et al., 2006, Dansi et al. 2008, Dansi et al. 2003, Dossou-Aminon 2014). For example, "Glassoman" (Crassocephalum spp.), a wild indigenous leafy legume, is rich in proteins and was widely consumed in forest zones of Benin. "Egusi" (Citrullus lanatus, Cucumeropsis manii, Lagenaria spp.), an ancient garden crop, and palm oil (obtained from processing fruits of oil palm-Elaeis guineensis) are rich in vitamins (especially vitamin A) and lipids. Egusi is rich in fat and vitamins $A, B_{1}, B_{2}, C$, and alpha-tocopherol, a component of vitamin E. It is composed of nearly $50 \%$ healthy fats and $30 \%$ protein. $^{2}$ Other traditional foods have medicinal values. ${ }^{3}$ Among them in Benin, "Tchayo" (Ocimum gratissimum) is widely recognized to prevent ulcer. In the context of above-mentioned transformations, markets are playing increasing important role, yet their integration with domestic food production areas seems still limited, as well as their positive impact on peoples' diets.

One aspect that has not been addressed by previous food marketing and food policy research in Benin is how the markets function for traditional foods versus introduced foods. ${ }^{4}$ There is a growing feeling that traditional foods are disappearing from diets of urban and rural people due to their decreasing availability resulting from growing urbanization, climate change, and poorly functioning markets (Friedmann and McMichael 1989, Atkins and Bowler 2001, Honfoga et al. 2005). An important way of appraising this market functioning is to assess market integration. This paper examines the differential market integration for traditional foods vs. introduced foods and how this affects food consumption patterns. It draws from findings of the research project entitled "the effects of market integration on the nutritional contributions of traditional foods to the wellbeing of the rural poor in Africa," which was implemented from 2010 to 2012 by Bioversity International in collaboration with partner research organizations in Benin (West Africa) and Kenya (East Africa). The first objective of the project was "to assess the relative nutritional benefits and related health outcomes of a diversity of locally produced traditional foods vs. introduced foods among the rural poor with varying degrees of market integration" (Bellon 2010). The market study component analyzes the effects of market integration on the consumption of traditional foods, in order to advise on appropriate policies that would foster greater availability of those foods and adequate changes in food consumption patterns. Regarding food diversity, findings by Bellon et al. (2016) using the project's database in Benin conclude that "on-farm and market diversities had a significant positive effect on mothers' dietary diversity, and that there is a positive relationship between on-farm diversity and dietary diversity among mothers. Production for selfconsumption and food purchases complement rather than replace each other in their contribution to dietary diversity and thus dietary quality." These findings imply that dietary diversity/quality is indifferent from a particular food source, be it self-production or market. Enough light was not shed on the issue of disappearance of traditional foods from the diets of people, nor has market integration been clearly referred to. 
This paper aims to enlighten on the status of market integration, and to know the extent to which it influences direct food substitution dynamics in the diets of rural people in Southern Benin. Rather than the source of procurement only (home/self-production vs. market), the issue at stake here is more about food type (traditional vs. introduced) ${ }^{5}$ and how market integration affects its presence in the diets overtime.

Relying on empirical data from the abovementioned market study, this paper aims to understand if market integration really plays a role in food habits in Southern Benin.

The following hypotheses are tested:

(i) Introduced foods show higher levels of market integration than traditional foods

(ii) Low levels of market integration among traditional foods contribute to their disappearance in the diets (food consumption frequency and diet composition).

The first hypothesis accrues from the observation that introduced foods are traded widely by merchants who move across all types of markets to make such "new foods" available to consumers (Lutz, 1994). Ascending trade flows of introduced foods from Cotonou to rural markets are faster and more regular than the downward flows of traditional foods which are mostly crude and seasonal. The second hypothesis has its theoretical ground in the relation between food availability, food market dynamics, and food consumption patterns (Smith and Haddad 2001; Honfoga and van den Boom 2003). Its practical justification pertains to several reasons. One is the second food régime earlier mentioned (Friedmann and McMichael 1989). Another reason is the growing imported dependency of Benin, most imported foods being the "introduced foods." However, besides market integration of introduced foods, the limited availability of traditional foods in the markets also explains the disappearance of these foods in the diets in Benin. It is linked to climate change, low availability of farm labor for women who mostly grow traditional foods, and changes in production systems towards monocropping of highvalue export crops (cotton, pineapple, cashew nuts, soya beans).

\section{Literature review}

\section{Traditional foods vs. introduced foods}

Traditional foods are said to be secular indigenous foods that are as old as the culture of people who eat them. The notion of ethnic foods (Cook et al. 1999) goes with them. They are core to ancient, endogenous food habits which were described in terms of the kind of customary and ritualized behavior that underpins the reproduction of a stable society together (Lupton 1996). Indeed, traditional foods played a major role in traditions of different cultures and regions for thousands of years including foods that have been consumed locally and regionally for an extended period (Centre of Research Excellence in Nutrition and Metabolism 2016). Traditional food refers to foods and dishes that are consumed over the long-term duration of civilization and have been passed through generations (Saunders 2010); traditional foods and dishes are traditional in nature, and may have a historic precedent in a national dish, regional cuisine or local cuisine (Kristbergsson and Oliveira 2016). Certain values and norms in eating patterns are symbolic of broader structures in society as a whole and may not be well perceived by outsiders (Goody 1982). On the contrary, introduced foods are quite new and are 
brought from outside the community or culture. Their introduction into food habits is quite recent, dating back to only a few decades, whereas traditional foods are being consumed by native peoples, since the very beginning of their settling in the area many centuries ago.

While traditional foods are mostly locally produced, introduced ones are mostly imported (Popkin 2003). Quite often, introduced foods are manufactured and more industrially processed than traditional foods. However, the frontier between the concepts of traditional and introduced foods is not neat. For example, some non-indigenous foods such as parboiled rice and wheat flour have been introduced into endogenous food habits long ago (since colonization times in Africa) and may be considered as traditional foods although they were mostly imported and consumed by middle- or high-income people. Likewise, "vegetal oil" is considered an introduced food, but it is a "mix" of several types of industrially processed vegetal oils and locally produced groundnut oil, which makes it also closer to a traditional food. Today, they are present in all households.

\section{Substitution of traditional foods for introduced foods}

The growing view that traditional foods are disappearing (Nzenza 2014) and are being replaced by introduced foods in the diets witnesses the perceived effects of the second food régime in the USA and Europe, where large industrial capitals began to dominate both sides of the agro-food chain and farm products became inputs to manufactured foods rather than products for final end use (Friedmann and McMichael 1989, p.103; Green and Griffith 2002; Honfoga et al. 2002). In SSA, environmental disasters (e.g., droughts, floods), forest destruction for agriculture, decreasing soil fertility, and crop failure due to diseases are important threats to traditional foods (Dossou-Aminon et al. 2014). At the heart of economic reasons is the second food regime, which is also present in SSA because of changing cropping and food systems where farmers are abandoning traditional foods for a few selected food and cash crops demanded by multinational food and fiber industries. Indeed, the diversion of farm labor to the production and processing of crops most demanded by Western countries' markets is also a reason of the disappearance of traditional foods. The increasing dependence of newly independent post-colonial states on imported food grains, such as wheat, from developed countries to feed their burgeoning populations was-and is still being-paid for by the greater production of industrial crops (e.g., cotton) and high-value tropical and temperate food crops, with damaging consequences for traditional, subsistenceoriented agricultural systems (Atkins and Bowler 2001, p.27). In general, weak food distribution system and decreasing income or growing poverty are the main drivers of perverse food substitution, unbalanced diets, and malnutrition in those countries (Atkins and Bowler, 2001, p.118; UNDP-Benin 2011, p.66 \& 73).

\section{Meanings and applications of the concept of market integration}

Market integration means the strength of trading networks that link different market outlets, i.e., market-sheds (Bellon 2010). The term market-shed is used to give the sense of a system or network of market flows within a given area (e.g., it is not just a zone with some markets located in it, but rather, it is a trading network with links between market outlets) (Anderson et al. 2010). The related market integration based on travel time is sensed from the observation that good infrastructure favors transportation and speed of trade flows from production centers to assembly and consumer markets, 
thereby enabling integration within a market-shed (Fafchamps and Gabre-Madhin 2006). Baulch (1997, p. 477) gives the importance of assessing market integration by linking spatial integration of markets, transmission of price signals from urban food deficit to rural food surplus areas, price volatility, specialization of agricultural producers according to long-term comparative advantage, and gains from trade. Therefore, market integration depends on and expresses the nature of physical and economic linkages (particularly market information) that exist between various production-consumption zones for a selected tradable product. The dynamics are reflected by price movements.

Therefore, two markets are said to be integrated for a given commodity if prices move together, i.e., price movements tend to behave similarly, reflecting the cost of transferring the product between two regions (Rashid and Minot 2010, Hossain and Verbeke 2010). World Food Programme (2001) made this definition more explicit as it affirmed that when markets are integrated, two conditions exist: (a) price are correlated, i.e., they move in tandem with one another, but at different levels that are determined by transaction costs (necessary yet insufficient condition of market integration); (b) commodities flow between markets, i.e., markets are integrated through trade, which triggers price transmission from one market to another (necessary and sufficient condition of market integration). However, the statistical interpretation of price correlation coefficients is problematic in a context where numerically low price correlations prevail despite other evidence that suggests competitive and rational behavior by a large number of market actors (Delgado 1986). Market integration is influenced by the type of markets (urban, semi-urban and rural). It is product-specific, and price dynamics is a core to assessing it more accurately (Chamberlin and Jayne 2013). Indeed, transaction costs are dynamic and vary by time, space, and product.

Delgado (1986) affirmed that "the yardstick of integration of a pair of village markets within a given season is that the price spread between them stays approximately constant, subject to random variation either way, over the weeks in the season in question." Lutz (1994) observed that spatial and temporal arbitrage are simultaneously taken into account by price co-integration models, the level of statistical significance of which is used to conclude whether the markets are integrated or not. The use of co-integration models is recommended to assess market integration for the sake of accuracy, considering the need to separate seasonal, trend, and stochastic variations in price time series or to jointly consider them. The critical question is "how do prices on two spatially separated markets adjust in the long and in the short run?" To answer this question, Ravallion (1986) developed an autoregressive distributed lag (ADL) model with the aim of assessing both the long-run and short-run adjustment process. A "dynamic" structure was developed to take account of the sluggishness of price adaptations. A distinction is made between short-run integration, defined as restrictive target of instantaneous adjustment corresponding to the market efficiency hypothesis (Malkiel 1987), and long-run integration, defined as a less restrictive target of price integration in the long run (Lutz 1994).

\section{Methods}

\section{Study area and selected foods and market clusters}

The semi-deciduous forest zone of Southern Benin, north of the Lama depression zone, was chosen for the study, based on the likelihood of substantial presence of traditional 
foods in that zone. Three districts were selected: Allada and Toffo (about 60 and $70 \mathrm{~km}$ north of Cotonou) in the Atlantique department and Bohicon (about $130 \mathrm{~km}$ north of Cotonou) in the Zou department (Fig. 1). The study area is characterized by rural populations with different levels of urbanization: higher urban vs. rural population densities (Bohicon district); higher rural vs. urban population densities (Allada district); and only rural population (Toffo district).

Traditional foods selected for this study include "egusi" (C. lanatus, C. manii, Lagenaria spp.), palm oil (derived from E. guineensis), groundnut (Arachis hypogaea), and maize (Zea mays). Introduced foods include vegetal oil and imported rice. Many others such as wheat (wheat products), Irish potato, and canned and other manufactured products were considered by the whole project. Within each district, selected villages are located at
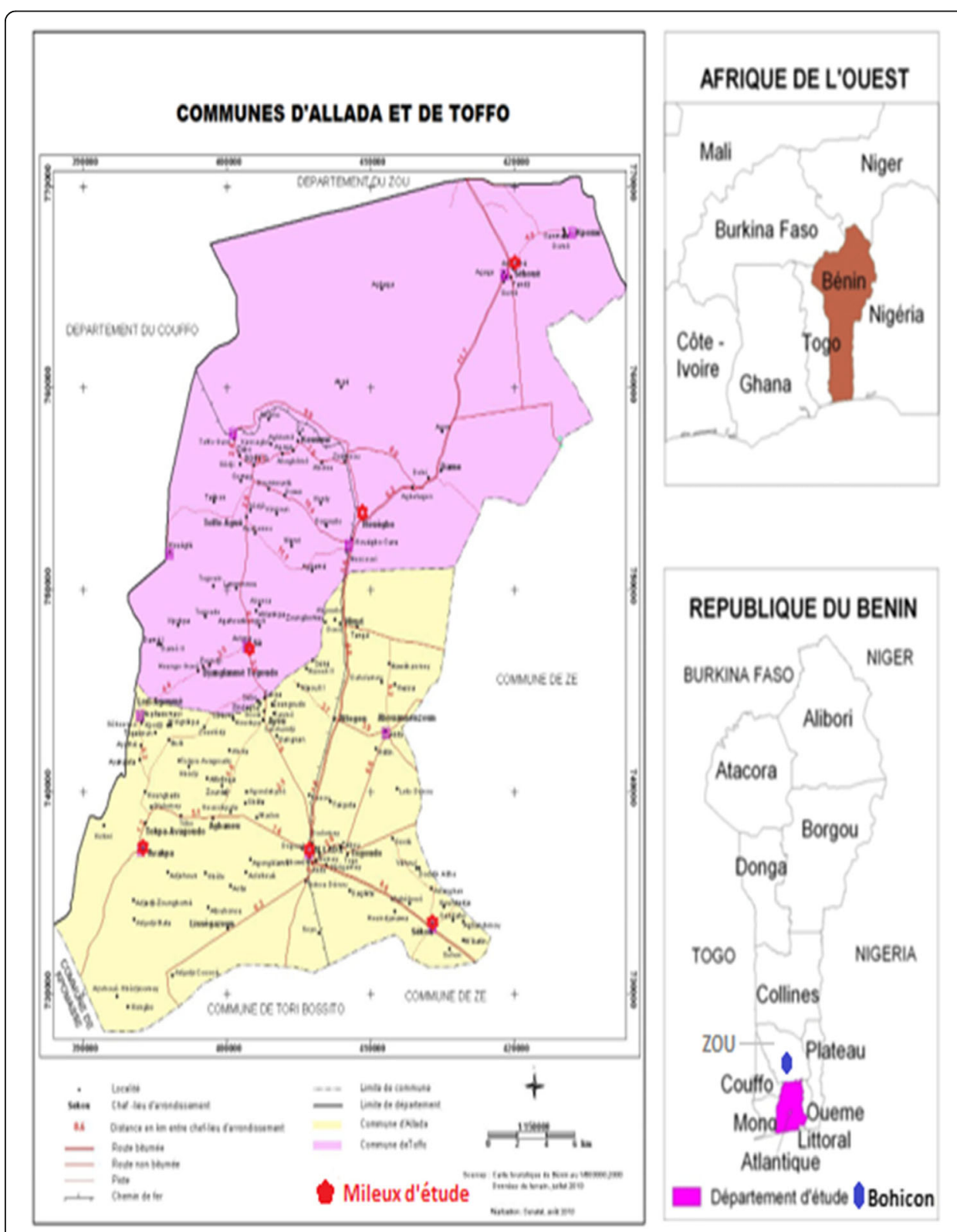

Fig. 1 Map of Benin. Study districts with location of study markets 
different traveling times to a reference market center. The set of villages within a district constitute a "market-shed" (Anderson et al. 2010), providing different opportunities for households to participate in and be influenced by a network of markets.

In order to assess market integration and test the hypotheses, the project recorded at fixed intervals the prices of key agricultural goods (including those listed above) traded in village markets. Prices were collected weekly by district-level agents of the state local agricultural service (CARDER), but only average monthly prices were reported in official agricultural statistics. The spread in these prices will be compared to that in key market towns with which the villages trade, as Baulch (1997) suggested. Product-wise and market-wise averages of relevant market integration indicators will be calculated. For that purpose, the following market clusters were considered: the Allada-Bohicon market cluster, which is composed of a primary market Avakpa, a rural assembly Sekou, a rural consumer market Allada-centre, and the Bohicon regional market, and the Toffo-Bohicon market cluster, which is composed in the same order of Sey, Sèhouè, Houègbo, and the Bohicon regional market (Table 1).

While long-distance trade of locally produced foods occurs from many rural assembly markets of central and southern Benin towards the international market of Dantokpa in Cotonou (Lutz 1994, Fanou et al. 1991), it is increasingly observed that substantial trade flows also go to the regional market of Bohicon. This market was selected for the study as the main regional semi-urban market because of the greater presence of traditional foods. Indeed, the trade of traditional foods occurs from the rural assembly markets of Sékou and Sèhouè directly towards the regional market of Bohicon, and sometimes via the Allada-centre and Houègbo. Trade flows of introduced (imported) foods go the other way round.

Trade interactions occur between the two market clusters to feed the regular trade flows between Sekou, Allada, Houègbo, Sèhouè, and Bohicon along the main tarred road Cotonou-Bohicon-Parakou. Anyway, Lutz (1994) considered both Bohicon and Dantokpa as urban consumer markets where agricultural products and manufactured goods are traded throughout the year.

\section{Empirical framework}

Two markets are said to be integrated for a given commodity if prices move together (Rashid and Minot 2010, Hossain and Verbeke 2010). Market integration is more accurately measured through the test of co-integration of market price series when

Table 1 Description of market clusters in the study area

\begin{tabular}{|c|c|c|c|}
\hline $\begin{array}{l}\text { Type of } \\
\text { market }\end{array}$ & Definition & $\begin{array}{l}\text { Allada- } \\
\text { Bohicon }\end{array}$ & $\begin{array}{l}\text { Toffo- } \\
\text { Bohicon }\end{array}$ \\
\hline Primary & $\begin{array}{l}\text { Market where producers sell directly their produce } \\
\text { to small-scale assemblers and village retailers }\end{array}$ & Avakpa & Sey \\
\hline Rural assembly & $\begin{array}{l}\text { District-level market that ensures produce assembly } \\
\text { from several village/primary markets for rural semi-wholesalers }\end{array}$ & Sekou & Sèhouè \\
\hline Rural consumer & District-level retail market & Allada-centre & Houègbo \\
\hline Regional & $\begin{array}{l}\text { Semi-urban market that gathers produce from assembly } \\
\text { markets for urban wholesalers }\end{array}$ & Bohicon & Bohicon $^{b}$ \\
\hline
\end{tabular}

${ }^{a}$ Also plays the role of rural assembly market, thanks to its historic position of embedding a railway station

${ }^{\mathrm{b}}$ Also embeds a railway station. It is a semi-urban consumer market 
adequate data are available. Co-integration models (Lutz 1994) are too data demanding. The price time series should be long enough (usually weekly prices over many years) and uniform and have little or no missing data. They should cover several abundance and lean periods of the agricultural product (Lutz 1994, p. 121; Delgado 1986).

Temple (2000) decomposed a price time series into trend, seasonality, and instability components as follows:

$$
\mathrm{Y}=\mathrm{T}^{*} \mathrm{~S}^{*} \mathrm{C}^{*} \mathrm{I}_{\mathrm{r}}
$$

where $Y=$ price time series of a given product, $T=$ trend component, $S=$ season component or seasonality index, $C=$ cyclical component, and $I_{\mathrm{r}}=$ irregular component associated with instability.

In short time series, the cyclical component $C$ could hardly be observed before 6 years for many foodstuffs in Cameroon (Temple and Dury 2003), and it was therefore combined with $I_{\mathrm{r}}$ to result into $I_{\mathrm{r}}{ }^{\prime}=C+I_{\mathrm{r}}$, and $Y$ became $Y={ }^{~}{ }^{*}{ }^{*} I_{\mathrm{r}}$ '. The instability component $I_{\mathrm{r}}$ or $I_{\mathrm{r}}{ }^{\prime}$ should be measured on the irregular component of the price time series (Scott and Griffon 1998). However, many irregular features can also be observed within the seasonal and cyclical components due to substantial variability between markets for local units of measurements in relation with the types of markets, products, traders/actors, transactions, and periods (Temple and Dury 2003).

In this study where price data series have less than 30 observations, comparing price instability coefficients between markets is proposed as an alternative to price correlation coefficients or co-integration models for measuring market integration.

The price instability coefficient has its theoretical justification in (i) the temporal volatility, i.e., the average variation from the mean that shows how stable a particular market is, and (ii) the spatial volatility, i.e., the correlation between prices over space at a given time (World Food Programme 2001).

Assessing market integration by comparing two markets for the price instability coefficient is therefore about appraising the dynamics of spatial volatility over time. This involves the comparison between markets of average price variation overtime. However, the average variation in the temporal variability should be measured from the trend (predicted price) rather than from the mean in the ordinary coefficient of variation.

The price instability coefficient (I) for a given market expresses the average price deviation from the trend in percentage of the mean price. Its formulae, as proposed by Heidingsfield and Blankenship (1974) is:

$$
\left.\mathrm{I}(\%)=100 *\left(\sqrt{\Sigma}\left(\ddot{\mathrm{Y}}_{\mathrm{i}}-\mathrm{Y}_{\mathrm{i}}\right)^{2}\right) /\left(\mathrm{T}^{*} \overline{\mathrm{Y}}\right)\right)
$$

where $\ddot{\Upsilon}_{\mathrm{i}}$ is the predicted price on the trend line $\left(\ddot{\Upsilon}_{\mathrm{i}}=\mathrm{a}+b t\right), t$ is the time or market day number;

$Y_{\mathrm{i}}$ is the actual price on market date $t$, and $\bar{Y}$ is the average price over $T$ number of market days or periods (months in this study). 
The trend component $(\tau)$ in Temple's equation is captured by the predicted price and the period's duration $T$ in Eq. 1 . The idea is quite similar in terms of harnessing the trend effect through the period's length in the appraisal of price instability.

In this paper, the reciprocal of absolute gap in price instability coefficients $(G)$ is used to establish the status of market integration in the selected market clusters. The lower the gap $(G)$ is, the greater the market integration would be. The aim is to use an indicator of market integration that can be reasonably related to food consumption in the surroundings of each market (see hypothesis 2). Neither statistical significance of a cointegration model nor a price correlation coefficient is appropriate for the purpose. Although such approach to assess market integration does not have previous direct reference in the literature, we believe it makes sense as revealed above by the theoretical link between price volatility and market integration. The approach relies on the basic assumption that price spread between two integrated markets stays approximately constant (Delgado 1986). If price spread is not constant, price instability coefficient will be high and market integration would be low. In other words, the greater is the gap in price instability coefficients, the less likely will price movements be parallel and the less will the markets be integrated.

Therefore, the price instability-based indicator of market integration $(G)$ between market 1 and market 2 is:

$$
G=1 / \operatorname{abs}\left(I_{2}-I_{1}\right)
$$

Where "abs" indicates the absolute value of the gap in price instability coefficients $I_{1}$ and $I_{2}, 0 \leq I_{1} \leq 100$ and $0 \leq I_{2} \leq 100$. The formula of the price instability coefficient was given in Eq. 1.

The larger the gap in price instability coefficients, the lower the $G$ will be, i.e., low market integration. The value of $G$ is undetermined or infinite when $I_{2}=I_{1}$, i.e., perfect parallelism of price movements in the two markets, meaning perfect market integration. For the purpose of comparisons, especially for testing hypothesis 2, the infinite values of $G$ will be set to 100 , through setting the zero gap to 0.01 . Product-wise and market-wise appraisals are made of $\mathrm{G}$ to identify the type of foods (traditional vs. introduced) which markets are best integrated for, and which types of market pairs (primary-assembly, primary-rural consumer, assembly-rural consumer, rural-regional) are the most integrated for the same type of foods. In the rural-regional appraisal, rural means primary, assembly, and rural consumer altogether.

Monthly retail price series of the selected traditional and introduced foods over the period July 2009-July 2011 were used for the analysis. These data were collected by the district bureaus of the Ministry of Agriculture. Although prices that are specific to markets' levels in the chain should have been considered, producer prices and wholesale prices were quite erratically available, whereas retail prices were regularly available in all markets. Therefore, retail prices were deemed more appropriate for the analysis, considering that they also reflect better the actual and overall level of supply-demand interactions in the said markets.

The relationship between food consumption and market integration in the second hypothesis was then tested using summaries of food consumption data collected by the project and the market integration indicator $G$. The detailed consumption data were obtained by interviewing rural households from the three districts during dry $(n=472)$ 
and wet $(n=482)$ seasons between 2011 and 2012. Villages within districts and their households were selected randomly according to market accessibility, with a mother selected for each household (Bellon et al. 2016). However, considering data availability for this paper, average values of consumption frequency over 174 households in Allada, 183 in Toffo, and 115 in Bohicon were used. With available nutrition data being only one-time cross-sectional data, spatial comparisons between market clusters is envisaged for testing the second hypothesis, which is therefore reformulated as: "Consumption of traditional foods decreases in the diets when market integration for introduced foods increases."

\section{Results and discussion}

\section{Product-wise and market-wise comparison of market integration}

Traditional foods selected for this study include egusi, palm oil, groundnut, and maize. Introduced foods include vegetal oil (commonly and wrongly called "groundnut oil" by women traders and consumers) and imported rice. Trends in the prices of these products are presented in Annex 1.

The price instability coefficient is the average deviation of prices from the trend, expressed as percentage the mean price. Table 2 shows the price instability coefficients for all selected products and their relative gaps between successive market pairs in the Allada cluster. In the primary market of Avakpa, its value is $5.25 \%$ for egusi in shells, i.e., deviation from the trend over 36 months is $5.25 \%$ the mean price. The lower the gap between the coefficients of two markets, the greater are these markets integrated. For the same product, Sekou assembly market is more integrated with the Allada

Table 2 Price instability coefficients (I) and gaps between successive market pairs in the AlladaBohicon market cluster

\begin{tabular}{lllll}
\hline Foods & $\begin{array}{l}\text { Primary market } \\
\text { Avakpa: } 1\end{array}$ & $\begin{array}{l}\text { Assembly market } \\
\text { Sékou: } 2\end{array}$ & $\begin{array}{l}\text { Consumer market } \\
\text { Allada: } 3\end{array}$ & $\begin{array}{l}\text { Regional market } \\
\text { Bohicon: 4 }\end{array}$ \\
\hline Egusi in shells & 5.25 & 3.39 & 3.49 & 0.86 \\
& & $(1.86)$ & $(0.1)$ & $(2.63)$ \\
Unshelled egusi & 3.98 & 4.26 & 4.16 & 0.80 \\
& & $(0.28)$ & $(0.1)$ & $(3.36)$ \\
Palm oil & 2.37 & 2.05 & 2.02 & 1.12 \\
& & $(0.32)$ & $(0.03)$ & $(0.9)$ \\
Groundnut in & 2.18 & 2.18 & 2.15 & - \\
shells & & $(0.00)$ & $(0.03)$ & \\
Maize & 1.57 & 1.49 & 1.4 & 0.66 \\
& & $(0.08)$ & $(0.09)$ & $(0.74)$ \\
Traditional & $\mathbf{3 . 0 7}$ & $\mathbf{2 . 6 7}$ & $\mathbf{2 . 6 4}$ & $\mathbf{0 . 8 6}$ \\
foods & & $\mathbf{( 0 . 4 0 )}$ & $\mathbf{0 . 0 3 )}$ & $\mathbf{( 1 . 7 8 )}$ \\
Vegetal oil & 1.83 & 1.87 & 1.97 & 1.74 \\
& & $(0.04)$ & $(0.10)$ & $(0.23)$ \\
Imported rice & 0.2 & 0.3 & 0.64 & 0.64 \\
& & $(0.10)$ & $(0.34)$ & $(0.00)$ \\
Introduced & $\mathbf{1 . 0 2}$ & $\mathbf{1 . 0 9}$ & $\mathbf{1 . 3 1}$ & $\mathbf{1 . 1 9}$ \\
foods & & $\mathbf{( 0 . 0 7 )}$ & $\mathbf{( 0 . 2 2 )}$ & $\mathbf{( 0 . 1 2 )}$
\end{tabular}

Number of observations: 25 (monthly prices, July 2009-July 2011)

Figures in parentheses are the absolute gaps between price instability coefficients $(I)$ for successive markets. They are put in italics in order to differentiate them from the actual price instability coefficients. Values in bold are product type-wise averages 
consumer market than with the Avakpa primary market, the gap in price instability coefficients being respectively 0.1 and 1.86 .

Derived from Table 2, values of the market integration indicator $G$ are computed in Table 3 for all products and relevant market pairs for a complete analysis. Average values of $G$ indicate that markets in the Allada market cluster are more integrated for introduced foods $(G=5.3)$ than traditional foods $(G=4.3)$. The integration of primary, assembly, and rural consumer markets with the Bohicon regional market is by far higher for introduced foods $(G=5.3)$ than traditional foods $(G=1.2)$. The district-level rural markets are also more integrated among themselves than with the regional market, either for traditional foods or introduced foods. The higher market integration for introduced foods than traditional foods is due to vegetal oil which has very low gaps in price instability coefficients and hence high values for the reciprocal, i.e., the $G$ indicator. Market integration is higher for palm oil and unshelled egusi than egusi in shells because the first two are processed foods and are more regularly and widely traded than the latter. Hence, the more is a food traded, the more integrated its markets would be. Processing of locally traded traditional foods is likely to improve market integration in rural market clusters. Indeed, processing is key among the factors that increase urban consumers' preferences for introduced foods against traditional foods (Adegbola and Singbo 2005). However, the basic food classification ("introduced" and "traditional") adopted in this study cannot strictly be assimilated to the groupings "processed" and "unprocessed foods." For example, palm oil is a processed food but remains traditional.

The market-wise analysis indicates that assembly and consumer markets are more integrated for traditional foods than is the case with primary market and the regional market or the rural consumer market. Low market integration between primary/assembly markets and consumer/regional markets is due not only to delays in produce transfer, resulting from bad road accessibility (distance and state of roads, and therefore travel times and transport costs), but also to the heterogeneity of critical marketing tools such as units of weight/volume of measurement (Temple and Dury 2003, Thodey 1969). Differential price and margin appraisal capacity of customers is also a probable explanation. For example, Chamberlin and Jayne (2013) found in Kenya that distances

Table 3 Price instability-based market integration indicator $(G)$ in Allada-Bohicon market cluster

\begin{tabular}{|c|c|c|c|c|c|}
\hline Foods & $\begin{array}{l}\text { Primary- } \\
\text { assembly }\end{array}$ & $\begin{array}{l}\text { Primary- } \\
\text { consumer }\end{array}$ & $\begin{array}{l}\text { Assembly- } \\
\text { consumer }\end{array}$ & $\begin{array}{l}\text { All rural markets-regional } \\
\text { market }^{\mathrm{a}}\end{array}$ & $\begin{array}{l}\text { Allada-Bohicon } \\
\text { market cluster }\end{array}$ \\
\hline Egusi in shells & 0.5 & 0.6 & 10 & - & - \\
\hline Unshelled egusi & 3.6 & 5.6 & 10.0 & 0.3 & 2.8 \\
\hline Palm oil & 3.1 & 2.9 & 33.3 & 1.0 & 3.2 \\
\hline Maize & 12.5 & 5.9 & 11.1 & 1.2 & 3.6 \\
\hline Traditional foods ${ }^{c}$ & 4.9 & 3.8 & 16.1 & 1.2 & 4.3 \\
\hline Vegetal oil & 25.0 & 7.1 & 10.0 & 6.3 & 5.3 \\
\hline Imported rice & 10.0 & 2.3 & 2.9 & 4.2 & 4.8 \\
\hline Introduced foods ${ }^{c}$ & 17.5 & 4.7 & 6.5 & 5.3 & 5.3 \\
\hline
\end{tabular}

${ }^{a}$ This features the rural-urban market integration appraisal, the regional market being the main consumption center

${ }^{\mathrm{b}}$ Average values here are row averages over market pairs. They are rounded to the next one-digit decimal

'Values in italics are product-wise averages 
to physical infrastructure are often not representative of farmers' access to markets; changes in specific market access conditions may have more to do with the behaviors of marketing agents. A very traditional food like egusi in shells illustrates the low market integration situation of this type of foods. Indeed, there are delays and lack of accuracy in the transmission of market information, especially for such raw/traditional food. On the contrary, all rural markets in Allada are quite uniformly integrated for vegetal oil, palm oil, and maize because those foods are well known to all market actors and are regularly and widely traded.

The results of the Toffo-Bohicon market cluster are reported in Tables 4 and 5. Price instability coefficients are quite constant, and the gaps between district-level market pairs are nil for most products, except maize and egusi in shells. Uniform or constant prices by market level in that district is the source of such results, giving the impression of quite perfect market integration between successive markets. There might have been a localized oligopoly by market level in the supply chains in that district, as Adegbidi et al. (2003) reported for maize in the Plateau department. However, the results confirm the trends in market integration that were observed for the Allada-Bohicon market cluster. For the purpose of testing the second hypothesis, the infinite values of $G$ indicator in this case are arbitrarily set to 100 , through setting the zero gap to 0.01 .

\section{Overall status of market integration in the study area}

The foregoing analysis leads to a few key concluding points on the status of market integration in the study area. Markets are more integrated for introduced foods than traditional foods, yet higher market integration for the processed foods vs. unprocessed

Table 4 Price instability coefficients and gaps between successive market pairs in the ToffoBohicon market cluster

\begin{tabular}{lllll}
\hline Foods & $\begin{array}{l}\text { Primary market } \\
\text { Sey: } 1\end{array}$ & $\begin{array}{l}\text { Assembly market } \\
\text { Sèhouè: } 2\end{array}$ & $\begin{array}{l}\text { Consumer market } \\
\text { Houègbo: } 3\end{array}$ & $\begin{array}{l}\text { Regional market } \\
\text { Bohicon: 4 }\end{array}$ \\
\hline Egusi in shells & 1.53 & $\begin{array}{l}2.11 \\
(0.58)\end{array}$ & $\begin{array}{l}2.11 \\
(0.00)\end{array}$ & 0.86 \\
Unshelled egusi & - & - & - & $(1.25)$ \\
& & & & 0.80 \\
Palm oil & 2.03 & 2.03 & 2.03 & 1.12 \\
& & $(0.00)$ & $(0.00)$ & $(0.91)$ \\
Groundnut in shells & 4.94 & 4.94 & 4.94 & - \\
& & $(0.00)$ & $(0.00)$ & 0.66 \\
Maize & 2.88 & 2.21 & 1.84 & $(1.18)$ \\
& & $(0.67)$ & $(0.37)$ & 0.86 \\
Traditional & 3.09 & 2.92 & 2.83 & $(1.97)$ \\
foods & & $(0.17)$ & $(0.09)$ & 1.74 \\
Vegetal oil & 1.67 & 1.67 & 1.67 & $(0.07)$ \\
& & $(0.00)$ & $(0.00)$ & 0.64 \\
Imported rice & 0.55 & 0.55 & 0.55 & $(0.00)$ \\
& & $(0.00)$ & $(0.00)$ & 1.19 \\
Introduced & 1.11 & 1.11 & 1.11 & $(0.12)$ \\
foods & & $(0.00)$ & $(0.00)$ &
\end{tabular}

Number of observations: 22 (monthly prices, July 2009-July 2011)

Figures in parentheses are the absolute gaps between price instability coefficients $(l)$ for successive markets. Figures in italics are product type-wise averages

- data not available 
Table 5 Price instability-based market integration indicator $(G)$ in Toffo-Bohicon market cluster

\begin{tabular}{|c|c|c|c|c|c|}
\hline Foods & $\begin{array}{l}\text { Primary- } \\
\text { assembly }\end{array}$ & $\begin{array}{l}\text { Primary- } \\
\text { consumer }\end{array}$ & $\begin{array}{l}\text { Assembly- } \\
\text { consumer }\end{array}$ & $\begin{array}{l}\text { All rural markets-regional } \\
\text { market }^{\mathrm{a}}\end{array}$ & $\begin{array}{l}\text { Toffo-Bohicon } \\
\text { market cluster }\end{array}$ \\
\hline Egusi in shells & 1.7 & 1.7 & 100.0 & - & 34.5 \\
\hline $\begin{array}{l}\text { Unshelled } \\
\text { egusi }\end{array}$ & - & - & - & - & - \\
\hline Palm oil & 100.0 & 100.0 & 100.0 & 1.1 & 75.3 \\
\hline Maize & 1.5 & 1.0 & 2.7 & 0.6 & 1.5 \\
\hline $\begin{array}{l}\text { Traditional } \\
\text { foods }^{c}\end{array}$ & 5.9 & 3.8 & 11.1 & 0.5 & 5.3 \\
\hline Vegetal oil & 100.0 & 100.0 & 100.0 & 14.3 & 78.6 \\
\hline $\begin{array}{l}\text { Imported } \\
\text { rice }\end{array}$ & 100.0 & 100.0 & 100.0 & 11.1 & 77.8 \\
\hline $\begin{array}{l}\text { Introduced } \\
\text { foods }{ }^{c}\end{array}$ & 100.0 & 100.0 & 100.0 & 12.5 & 78.1 \\
\hline
\end{tabular}

${ }^{a}$ This features the rural-urban market integration appraisal, the regional market being the main consumption center

${ }^{b}$ Average values here are row averages over market pairs. They are rounded to the next one-digit decimal

${ }^{\mathrm{C}}$ Figures in italics are product type-wise averages

- data not available

foods is a more relevant standpoint for food trade policies. District-level rural markets are more integrated with each other than with the regional market of Bohicon. Assembly and rural consumer markets are more integrated to the regional market than are primary markets with the regional market. This is due to low consumer price variations in the regional market, whereas larger price variations occur in the primary markets than in the assembly and rural consumer markets. The latter are strongly integrated, either for traditional foods or introduced foods.

\section{Relationship between market integration and food consumption}

The second hypothesis is formulated to check if consumption of traditional foods decreases when market integration for introduced foods increases. This means observing what happens to both variables (market integration and food consumption) when one moves from a producer area (with a certain number of rural markets) to a consumption area (with at least two major consumer markets or market towns). Unfortunately, final consumer price data were collected only on the Bohicon regional consumer market. The consumption data available include food consumption frequency (in number of days/week) and diet composition in terms of food presence or not in the diet. Testing of the above relationship goes this way: The variation of traditional foods' consumption frequency is compared to that of $G$ value of introduced food. The results show that while average consumption frequency of traditional foods remained the same in both clusters (5 times/week in average), the index of market integration for introduced foods increased from 5.3 in Allada-Bohicon market cluster to 78.1 in Toffo-Bohicon market cluster (Table 6). This means greater market integration for introduced foods did not alter the frequency of traditional foods' consumption. Likewise, while average consumption of introduced foods remained constant at twice a week, market integration of traditional foods rather increased slightly from 4.3 to 5.3 . This means greater market integration of traditional foods did not modify the frequency of introduced foods consumption. 
Table 6 Food consumption frequency and composite market integration index in Allada-Bohicon and Toffo-Bohicon market clusters

\begin{tabular}{|c|c|c|c|c|c|}
\hline \multirow[t]{2}{*}{ Foods } & \multicolumn{3}{|c|}{$\begin{array}{l}\text { Food consumption } \\
\text { frequency } \\
\text { (days/week) }^{\mathrm{a}}\end{array}$} & \multicolumn{2}{|c|}{$\begin{array}{l}\text { Market integration } \\
\text { indicator } G\end{array}$} \\
\hline & Allada & Toffo & Bohicon & $\begin{array}{l}\text { Allada-Bohicon } \\
\text { cluster }\end{array}$ & $\begin{array}{l}\text { Toffo-Bohicon } \\
\text { cluster }\end{array}$ \\
\hline Egusi & - & 7 & - & 2.8 & 34.5 \\
\hline Maize & 6 & 6 & 4 & 3.6 & 1.4 \\
\hline Palm oil & 4 & 2 & 5 & 3.2 & 75.3 \\
\hline Traditional foods ${ }^{\mathrm{b}}$ & 5 & 5 & 5 & 4.3 & 5.3 \\
\hline Vegetal oil & 2 & 2 & 2 & 6.3 & 78.6 \\
\hline Rice & 1 & - & 2 & 4.2 & 77.8 \\
\hline Introduced foods ${ }^{b}$ & 2 & 2 & 2 & 5.3 & 78.1 \\
\hline $\begin{array}{l}\text { Variation between traditional and introduced foods } \\
(\%)\end{array}$ & $-\overline{60}$ & $\begin{array}{l}- \\
60.0\end{array}$ & -60.0 & +23.2 & +13.7 \\
\hline
\end{tabular}

aalues of consumption frequency are averages of 174 households in Allada, 183 in Toffo, and 115 in Bohicon

${ }^{b}$ Figures in italics are product type-wise averages

- data not available

More swiftly, looking only at what happens in each market cluster, it appears that market integration was higher for introduced foods than traditional foods $(+23.2 \%$ variation in Allada-Bohicon cluster and $+13.7 \%$ in Toffo-Bohicon cluster), whereas consumption frequency of traditional foods was rather higher (60\% in both clusters). Obviously, higher market integration for introduced foods was not associated with reduced consumption frequency of traditional foods. The second hypothesis is therefore rejected.

Alternatively, considering households' diet composition with regard to the share of traditional foods ${ }^{6}$ in relation with market integration for introduced foods, AlladaBohicon market cluster stands for $55 \%$ traditional foods in diets and a market integration index for introduced foods of 5.3 , against $56 \%$ and 78.1 , respectively, for ToffoBohicon market cluster (Table 7). This result confirms the findings in Table 6 that consumption of traditional foods did not change significantly when market integration for introduced foods increased.

\section{Conclusions}

This study assessed the status of market integration in the selected study areas where traditional foods are available but not traded enough. The hypothesis according to which rural markets are more integrated for introduced foods than traditional foods is accepted. On the contrary, the hypothesis which asserts that consumption of traditional foods decreases with increasing market integration for introduced foods is rejected. Although rural markets are more integrated for introduced/imported foods than local/ traditional foods, the diets in rural areas of Benin are still dominated by locally

Table 7 Share of traditional foods in diets and market integration for introduced foods

\begin{tabular}{llll}
\hline District & $\begin{array}{l}\text { Average number } \\
\text { of foods in diet }\end{array}$ & $\begin{array}{l}\text { Share of crop-derived } \\
\text { traditional foods (\%) }\end{array}$ & $\begin{array}{l}\text { Index of market integration for } \\
\text { introduced foods with Bohicon }\end{array}$ \\
\hline Allada & 27.7 & 55.9 & 5.3 \\
Toffo & 25.0 & 57.0 & 78.1 \\
Bohicon & 29.3 & 54.2 & - \\
\hline
\end{tabular}

- not applicable 
produced foods. But the time dimension of that hypothesis could not be considered due to the non-availability of multiyear survey data for comparing diet dynamics with market integration overtime.

However, it is worth emphasizing that the more processing foods undergo, the more they are traded, and the more integrated their markets are likely to be. Manufactured foods are greatly demanded due to their cooking abilities; they can also be easily transported and therefore have greater access to markets, a situation which fosters greater market integration. In other words, the hidden reason behind market integration in the study area is the trade potentials of the different foods. Food processing to enable wider and long-distance trade is necessary to foster market integration of traditional foods. However, the growing trend in the consumption of introduced/imported foods should be curbed down by appropriate policies that would favor availability and accessibility of traditional foods to the poor.

\section{Endnotes}

${ }^{1}$ Import dependency rate $=$ percentage share of imports in total net supply, the latter being production + imports - exports.

${ }^{2} \mathrm{G}+\mathrm{W}$ Blog. $\mathrm{G}+\mathrm{W}$ Blog. Egusi, the Organic West African Miracle Food. http:// godandwheatgrass.com/2013/07/egusi-an-organic-miracle-food/. Accessed 11 April 2016.

${ }^{3}$ Source: https://globalfoodbook.com/benefits-of-ocimum-gratissimum-nchanwu-leaf.

${ }^{4}$ These two concepts are defined and discussed later in the "Literature review" section.

${ }^{5}$ See detailed discussion in the literature review.

${ }^{6}$ Adapted from the project's database on households' diet composition. Only cropderived traditional foods were considered in calculating the share based on number not quantities - of traditional foods in total diet.

\section{Acknowledgements}

We acknowledge the technical and institutional collaboration of the Faculty of Agronomic Sciences, University of Abomey-Calavi. We also thank Mrs. Blandine A. Ekpodilè, MSc, Environmental Sciences and Agricultural Economics, for her dedicated and sustained research assistantship.

\section{Funding}

This study was a component of the research project entitled "the effects of market integration on the nutritional contributions of traditional foods to the well-being of the rural poor in Africa" which was financed by the Bill and Melinda Gates Foundation and implemented by Bioversity International.

\section{Availability of data and materials}

Data used for this study are available at Bioversity International, Benin Station. They can be shared only with the permission of this organization.

\section{Authors' contributions}

Author BGH designed the methodology of the study and performed the data analysis and interpretation. Author GN-B organized the data collection, data archiving, and institutional support for the research. Author RSV provided useful agronomic and policy insights to the study. Author MRB supplied fresh literature and oriented the study results to focus. Author JDH contributed to highlighting the nutrition policy implications of the study. All authors participated in the writing and revision of the paper. All authors read and approved the final manuscript.

\section{Authors' information}

Author BGH is a PhD, Agricultural Economics, and a marketing expert and a deputy head, School of Economics, SocioAnthropology and Communication for Rural Development, Faculty of Agronomic Sciences, University of AbomeyCalavi, Benin.

Author GN-B is a PhD, Nutrition Sciences, and a project coordinator at the Bioversity International, Benin Station. Author RSV is a PhD, Agronomy, and was Benin country director of the Bioversity International at the moment of the study. 
Author MRB is a PhD, Sociology, and previously a project leader at the Bioversity International Headquarters (Rome). Author JDH is a PhD, Nutrition Sciences and Dean of the Faculty of Agronomic Sciences, University of Abomey-Calavi.

\section{Competing interests}

The authors declare that they have no competing interests.

\section{Publisher's Note}

Springer Nature remains neutral with regard to jurisdictional claims in published maps and institutional affiliations.

\section{Author details}

${ }^{1}$ Faculty of Agronomic Sciences, University of Abomey-Calavi, 03 BP 2819 Cotonou, Jericho, Benin. ${ }^{2}$ Bioversity International-Benin Station, c/o IITA/Benin Research Station, 08 B.P. 0932 Cotonou, Benin. ${ }^{3}$ Comisión Nacional para el Conocimiento y Uso de la Biodiversidad (CONABIO), Liga Periférico-Insurgentes Sur No. 4903, Tlalpan, 14010 Mexico City, Mexico.

Received: 12 August 2016 Accepted: 7 January 2018

Published online: 26 January 2018

\section{References}

Abegunde DO, Mathers CD, Adam T, Ortegon M, Strong K (2007) The burden and costs of chronic diseases in lowincome and middle-income countries. Lancet 370(9603):1929-1938

Achigan Dako GE, Fanou N, Kouke A, Avohou H, Vodouhe RS, Ahanchede A (2006) Évaluation agronomique de trois espèces de Egusi (Cucurbitaceae) utilisées dans l'alimentation au Bénin et élaboration d'un modèle de prédiction du rendement. Biotechnol Agron Soc Environ 10(2):121-129

Adegbidi A, Dedehouanou H, Kpenavoun S, Lutz C (2003) Dix ans de libéralisation du marché de maïs au Bénin. In: CDS research report no. 20. Centre for Development Studies, University of Groningen, Netherlands.

Adegbola PY, Komlan-Ahihou CM, Adegbidi A, Adetonah S, Coulibaly O, Mensah G-A, Montcho CMD (2016) Marketing of Jew's mallow in Agbedranfo local area in the southwest of Benin. Afr J Mark Manage 8(3):20-31 June 2016. DOl: 10.5897/AJMM2016.0486

Adegbola PY, Singbo AG (2005) Impact of imports of rice on the competitiveness and profitability of domestic production in Benin Republic. In: WARDA (ed) Proceedings of the regional workshop on "Policy and strategies to promote rice production and food security in sub-Saharan Africa", Cotonou, Benin Republic

Anderson CL, Lipper L, Dalton TJ, Smale HJ, Hodgkin T, Almekinders CJ et al (2010) Project methodology: using markets to promote the sustainable utilization of crop genetic resources. In: Lipper L, Anderson CL, Dalton TJ (eds) Seed trade in rural markets. Earthscan, London, pp 31-50

Arinloye AD (2006) Analysis of factors determining rice demand in central and southern Benin. In: Thesis of "Ingenieur Agronome". Faculty of Agronomic Sciences, University of Abomey-Calavi, Benin

Assogbadjo AE, Glèlè Kakaï R, Vodouhê FG, Djagoun CAMS, Codjia JTC, Sinsin B (2011) Biodiversity and socioeconomic factors supporting farmers' choice of wild edible trees in the agroforestry systems of Benin (West Africa). Forest Policy Econ 14:41-49

Atkins PJ, Bowler IR (2001) Food in Society: Economy, Culture, Geography. Holder Headline Group, 338 Easton Road, London NW1 3BH/Oxford University Press Inc., 198 Madison Avenue, New York, NY10016

Baulch B (1997) Transfer costs, spatial arbitrage and testing for food market integration. Am J Agric Econ 79(2):477-487

Bellon M (2010) The effects of market integration on the nutritional contributions of traditional foods to the well-being of the rural poor in Africa. Project concept note, Bioversity International, Italy

Bellon MR, Ntandou-Bouzitou GD, Caracciolo F (2016) On-farm diversity and market participation positively influence dietary diversity of rural mothers in southern Benin, West Africa. PLoS One September 8, 2016: https://doi.org/10. 1371/journal.pone.0162535

Bowler I (ed) (1992) The geography of agriculture in developed market economies. Longman, Harlow

Centre of Research Excellence in nutrition and metabolism (CENM) (2016) Traditional Food, http://srbnutrition.info/ english/traditional-foods. Accessed 11 Apr 2016

Chamberlin J, Jayne TS (2013) Unpacking the meaning of 'market access': evidence from rural Kenya. World Dev 41: 245-264 http://dx.doi.org/10.1016/j.worldev.2012.06.004

Cook I, Crang P, Thorpe M (1999) Eating into Britishness: multicultural imaginaries and the identity politics of food. In: Roseneil S, Seymout J (eds) Practising identity powers and resistance. Macmillan, Basingstoke, pp 223-248

Dansi A, Adjatin A, Adoukonou-Sagbadja H, Falade V, Yedomonhan H, Odou D, Dossou B (2008) Traditional leafy vegetables and their use in the Benin Republic. Genet Resour Crop Evol 55:1239-1256. https://doi.org/10.1007/ s10722-008-9324-z

Dansi A, Vernier P, Marchand J-L (2003) Les variétés d'igname cultivées : Savoir-faire paysan au Bénin. Groupe de Travail Interdépartemental sur la Biodiversité dans I'Alimentation et I'Agriculture. FAO, Rome

Dawson J, Burt S (1998) European retailing: dynamics, restructuring and development issues. In: Pinder D (ed) The new Europe: economy, society and environment. John Wiley, Chisester, pp 157-176

Delgado CL (1986) A variance components approach to food grain market integration in northern Nigeria. Amer J Agr Econ 68:4 November 1986

Dossou-Aminon I, Loko LY, Adjatin A, Dansi A, Elangovan M, Chaudary P, Vodouhê R, Ambaliou S (2014) Diversity, genetic erosion and farmer's preference of sorghum varieties [Sorghum bicolor (L.) Moench] in north-eastern Benin. Int J Curr Microbiol App Sci 3(10):531-552

Fafchamps M, Gabre-Madhin E (2006) Agricultural markets in Benin and Malawi. In: University of Oxford (UK) and IFPRI, programme of the ESRC Global Poverty Research Group 
Fanou LK, Lutz CHM, Salami S (1991) Les relations entre les marchés de maïs du Bénin et les marchés des espaces avoisinants au Togo, au Niger et au Nigéria. FSA/UNB, Cotonou and University of Amsterdam

FAO/PAR - FAO and Platform for Agrobiodiversity Research (2010) Biodiversity for food and agriculture contributing to food security and sustainability in a changing world. In: Outcomes of an expert workshop held by FAO and PAR from 14-16 April 2010 in Rome, Italy. FAO, Rome

FAO/ECOWAS (2015) Inputs into FAO contribution to ECOWAP +10 conference. Key findings and messages from AGWA. An ECOWAP policy review report, ECOWAS, Lomé, Togo

Friedmann H, McMichael P (1989) Agriculture and the state system: the rise and decline of national agriculture, 1870 to present. Sociol Rural 29:93-117

Gómez MI, Barret CB, Raney T, Pinstrup-Andersen P, Meerman J, Croppenstedt A, Carisma B, Thompson B (2013) Postgreen revolution food systems and the triple burden of malnutrition. Food Policy 42:129-138

Goody J (1982) Cooking, cuisine and class: a study in comparative sociology. Cambridge University Press, Cambridge

Green D, Griffith M (2002) Dumping on the Poor: The Common Agricultural Policy, the WTO and International Development. CAFOD, United Kingdom. https://www.iatp.org/files/Dumping_on_the_Poor_The_Common_ Agricultural_Po.htm

Heidingsfield MS, Blankenship AB (1974) Marketing. In: Harper and Row, Barnes and Noble Book Edition

Hollinger F, Staatz J (2015) Croissance agricole en Afrique de l'Ouest : facteurs déterminants de politique et de marché. $\mathrm{BAfD/FAO}$, Rome

Honfoga BG, Keita MS, Abbey G (2005) Foodgrain market instability and regional trade in the SADAOC zone. In: A medal finalist paper presented at the $6^{\text {th }}$ annual global development conference. Global Development Network (GDN), Dakar, Senegal 22-26 January 2005

Honfoga BG, Pérez M, Chinkanda NE, Rinzin C, Narayan NC (2002) Tina and the milk: southern perspectives on sustainability in the Netherlands. Published by NSDO, the Netherlands August 2002

Honfoga BG, van den Boom GJM (2003) Food-consumption patterns in Central West Africa, 1961 to 2000, and challenges to combating malnutrition. In: Food and nutrition bulletin, vol. 24, no. 2 ๑ 2003, the United Nations University

Hossain MI, Verbeke W (2010) Evaluation of rice markets integration in Bangladesh. Lahore J Econ 15(2):77

Kristbergsson K, Oliveira J (2016) Traditional foods: general and consumer aspects. In: Integrating food science and engineering knowledge into the food chain. Springer, US, pp 85-86 ISBN 978-1-4899-7648-2

Lupton D (1996) Food, the body and the self. Sage, London

Lutz CHM (1994) The functioning of the maize market in Benin: spatial and temporal arbitrage on the market of a staple food crop. PhD thesis, University of Amsterdam, The Netherlands

MAEP (2010) Strategic Plan for Boosting the Agricultural Sector in Benin (PSRSA), final version, August 2010. Ministry of Agriculture, Cotonou

Malkiel B (1987) Efficient market hypothesis. In: Eatwell J, Milgate M, Newman P (eds) The New Palgrave Dictionary of Economics. MacMillan Press, London, pp 120-122

Nzenza S (2014) Our disappearing traditional foods. Blog in The Herald, March 18, 2014. http://www.herald.co.zw/ourdisappearing-traditional-food/. Accessed 11 Apr 2016

Popkin BM (2003) The nutrition transition in the developing world. Dev Policy Rev 21(5-6):581-597

Rashid S and Minot N (2010) Are staple food markets in Africa efficient? Presented at the COMESA policy seminar "Food price variability: causes, consequences, and policy options" on 25-26 January 2010 in Maputo, Mozambique under the COMESA-MSU-IFPRI African Agricultural Markets Project (AAMP).

Ravallion M (1986) Testing market integration. Am J Agric Econ Volume 68(1):102-109, https://doi.org/10.2307/1241654

Saunders R (2010) What are traditional foods? Agriculture Society, October 28, 2010. http://agriculturesociety.com/ politics-and-food/what-are-traditional-foods/. Accessed 11 Apr 2016

Scott G, Griffon D (1998) Prix produits acteurs. Méthodes pour analyser la commercialisation agricole dans les pays en développement. Editions Khartala, Paris, p 489

Smith LC, Haddad L (2001) How important is improving food availability for reducing child malnutrition in developing countries? Agric Econ 26:191-204

Temple L (2000) Modèle de décomposition des séries chronologiques. In: Application au plantain au Cameroun, Njoumbé, Document du CRBP, no 207, p 18

Temple L, Dury S (2003) Instabilité du prix des produits vivriers et sécurité alimentaire urbaine au Cameroun. Série Urbanisation, alimentation et filières vivrières, In : CIRAD Document no. 6. Cadre méthodologique d'analyse des relations entre prix des vivriers et insécurité alimentaire. CIRAD, Montpellier

Thodey AR (1969) Analysis of staple food price behavior in W. Nigeria. Ph.D. Dissertation, University of Illinois

UNDP-Benin (2011) National Report on Human Development 2010-2011. UNDP Benin office, Cotonou, Benin

World Food Programme (2001) Market Analysis Framework: Tools and Applications for Food Security Analysis and DecisionMaking. United Nations World Food Programme, Rome, Italy. http://www.wfp.org/food-security;wfp.vaminfo@wfp.org 